\title{
The case of synchronous fallopian tube and endometrium cancer. Clinical observation
}

\author{
A. M. Romaniuk, N. I. Gyryavenko, M. S. Lyndin, V. V. Sikora, A. M. Piddubnyi \\ Sumy State University, Ukraine
}

Background. The problems of pre-operative cancer diagnosis of the fallopian tube are associated with a rare occurrence
of this disease. More rarely, there is a combination of the fallopian tube cancer and other gynecological tumors. Clinical ob-
servation of the fallopian tube cancer and endometrial cancer in postmenopausal woman is presented, which demonstrates
the difficulty of the pre-operative diagnostics of these pathologies combination.

Case presentation. We described a case of uterine tube cancer in Ukrainian woman (77 years), which had been combined with adenocarcinoma of an endometrium.

Conclusion. Primary fallopian tubes carcinoma is a rare disease with an insufficiently studied etiology. The clinical manifestations are not always present in full. Diagnosis in pre-operative period is very hard to establish. Only the qualitative morphological investigation allows establishing the primary lesion of the fallopian tube. Introducing immunohistochemical investigations in practice serves as additional methods for correct diseases diagnostic, which allow more fully characterizing the prognosis and suggesting appropriate treatment of the patients.

\section{Випадок синхронного раку маткової труби та ендометрія. Клінічне спостереження}

\section{А. М. Романюк, Н. І. Гирявенко, М. С. Аиндін, В. В. Сікора, А. М. Підаубний}

Проблеми доопераційної діагностики раку маткової труби пов'язані з рідкістю виникнення цього захворювання. Ще рідше спостерігають поєднання раку маткової труби та інших гінекологічних пухлин. Наведено клінічне спостереження раку маткової труби та раку ендометрія в жінки в постменопаузі, яке демонструє складності доопераційної діагностики комбінації цих патологій.

Представлення випадку. Описали випадок раку маткової труби в української жінки (77 років), який поєднувався 3 аденокарциномою ендометрія.

Висновки. Первинний рак маткових труб є рідкісною патологією з недостатньо вивченою етіологією. Клінічні прояви не завжди наявні в повному обсязі. Діагноз у передопераційному періоді встановлюють рідко. Тільки якісне морфологічне дослідження дає можливість визначити первинність ураження маткової труби. Впровадження імуногістохімічних досліджень у практику є додатковим методом для правильної діагностики захворювань, які дають змогу точніше охарактеризувати прогноз і запропонувати адекватні методи лікування пацієнтів.
Key words: adenocarcinoma Fallopian tube, prognosis.

Pathologia 2018; 15 (1), 109-113

Dol:

10.14739/2310-1237. 2018.1.129192

\section{E-mail:}

pathomorph@gmail.com,

n.gyryavenko@

med.sumdu.edu.ua

\section{Ключові слова:}

первинна аленокарцинома, фаммопієва труба, прогноз.

Патологія. - 2018. -

T. 15, № 1(42). -

C. 109-113

\section{Случай синхронного рака маточной трубы и эндометрия. Клиническое наблюдение}

\section{А. Н. Романюк, Н. И. Гирявенко, Н. С. Аындин, В. В. Сикора, А. М. Поддубный}

Проблемы дооперационной диагностики рака маточной трубы связаны с редкой встречаемостью данного заболевания. Еще реже отмечают сочетание рака маточной трубы и других гинекологических опухолей. Представлено клиническое наблюдение рака маточной трубы и рака эндометрия у женщины в постменопаузе, которое демонстрирует сложности дооперационной диагностики комбинации данных патологий.

Представление случая. Описали случай рака маточной трубы у украинской женщины (77 лет), который сочетался с аденокарциномой эндометрия.

Выводы. Первичный рак маточных труб - редкая патология с недостаточно изученной этиологией. Клинические проявления не всегда присутствуют в полном объеме. Диагноз в предоперационном периоде устанавливают редко. Только качественное морфологическое исследование позволяет установить первичность поражения маточной трубы. Иммуногистохимические исследования на практике служат дополнительными методами для правильной диагностики заболеваний, позволяют более полно охарактеризовать прогноз и предложить адекватные методы лечения пациентов.

\section{Background}

To date, the fallopian tube tumors are ranged from $0.3 \%$ to $1.1 \%$ of all malignant tumors of the female genital organs, being the most rare oncogynecology disease [1]. It was described for the first time in 1847 by Reno. According to available statistics, in average 3.6 cases of malignant fallopian tube tumors per 1 million women [2,3] are registered annually in the United States. The most of the malignant fallopian tube tumors have epithelial nature and are presented by serous adenocarcinomas (60-90\%); however, in practical activities almost all morphological forms of epithelial and stromal neoplasms occur [4]. Diagnostics of this tumor is difficult, due to the low severity of the clinical picture. According to literature data, the frequency of the diagnosis of this pathology on pre-operative stage fluctuates up to $21 \%[3,5]$.
Киючевые слова: первичная аленокарцинома, фамлопиева труба, прогноз .

Патология. - 2018. T. 15, № 1(42). -

C. $109-113$ 
Sometimes the fallopian tube cancer (FTC) is a random finding during the surgery on the uterus and parovarium with other diseases. More than $60 \%$ cases of the FTC occur with postmenopausal women [6]. However till now the risk factors of this disease remain insufficiently studied. These include reproductive tract infections, genetic factors (the presence of the defective gene BRCA1 and BRCA2) and others [7]. Fallopian tubes are frequently secondarily affected, provided the ovarian, uterus body, gastrointestinal tract, mammary glands are affected for the first time. Development of the synchronous tumors in oncogynecology ranges to $6 \%$ cases maximum [8], even more rarely it is possible to find a combination of the fallopian tube tumors and other gynecological tumors. We present a clinical case of the patient with the primary fallopian tube cancer (PFTC) in combination with endometrial cancer. This case report of the relatively rare disease demonstrates the nonspecific clinical course and the difficulty of timely disease diagnostics.

Table 1. Antibodies for immunohistochemical reaction

\begin{tabular}{|l|l|l|l|l|}
\hline Antibody & Host & Clone & Dilution & $\begin{array}{l}\text { Cellular } \\
\text { localization }\end{array}$ \\
\hline$E R \alpha$ & Rabbit & SP1 & $1: 200$ & Nuclear \\
\hline$P R$ & Rabbit & YR85 & $1: 150$ & Nuclear \\
\hline$p 53$ & Mouse & SP5 & $1: 100$ & Nuclear \\
\hline Ki-67 & Rabbit & SP6 & $1: 100$ & Nuclear \\
\hline
\end{tabular}
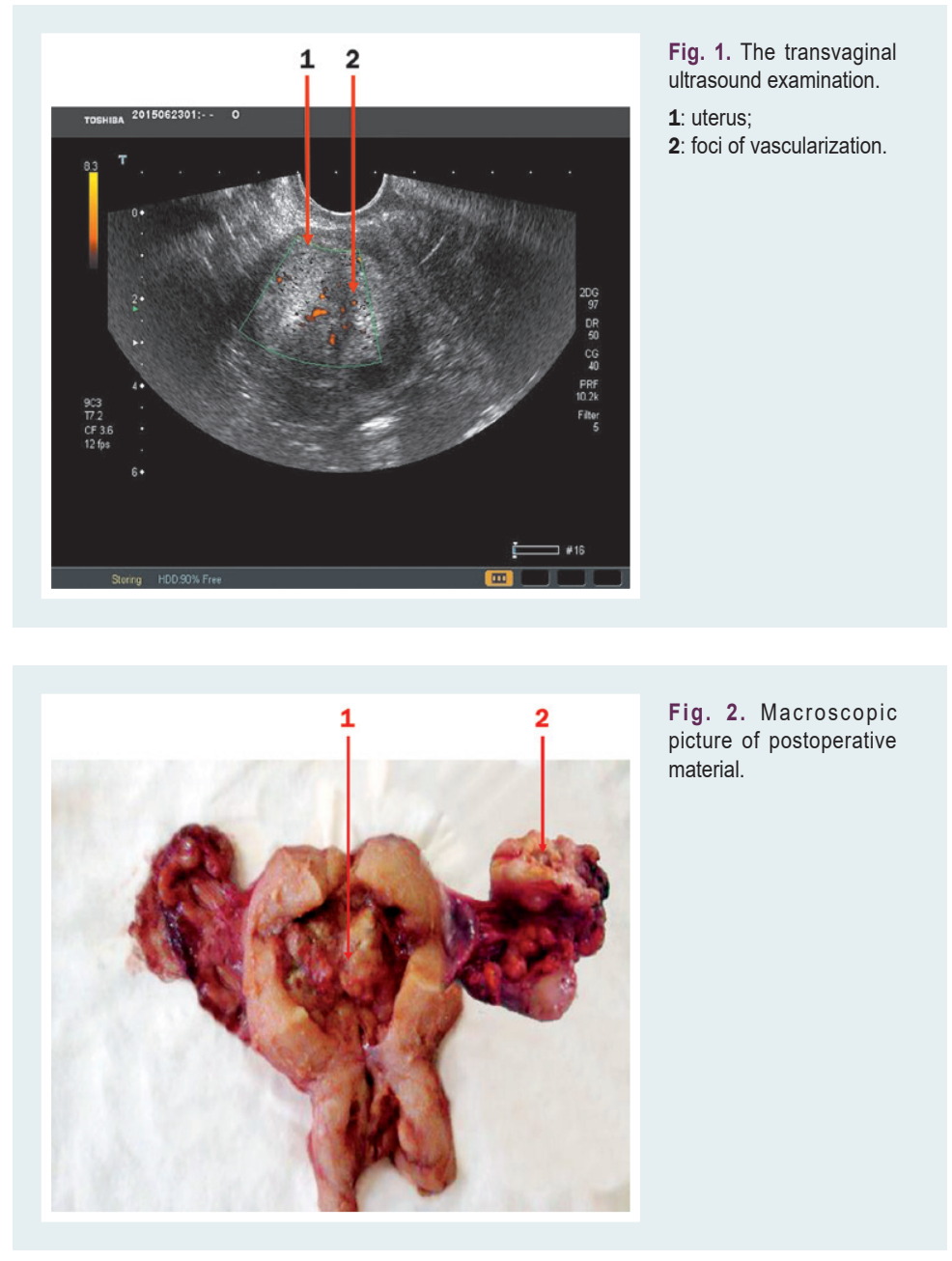

\section{Case presentation}

A 77-year-old Ukrainian female patient was admitted to the Clinical Oncological Dispensary with complaints on bleeding from the genital organs. Menopause is during 24 years. Complaints have appeared about a year ago. A family oncological anamnesis of the patient was not burdened. Gynecological examination revealed that the uterus is not enlarged, relatively movable, uterine appendages are not palpable.

The transvaginal ultrasound examination: endometrial hyperplasia with increased vascularization, uterine appendages are unchanged (Fig. 1).

In order to establish the diagnosis endometrial biopsy in the dashed scrapings form was performed. The result of histological examination showed growth of the highly differentiated endometrioid adenocarcinoma (ICD - C 54.1).

After X-ray examination of lungs pathological changes were not found. Laboratory researches showed the presence of the leukocytosis $\left(12.5 \times 10^{9}\right)$ in the blood, but the other indicators were presented in the normal range.

The diagnosis was the following: a malignant neoplasm of the uterus body (endometrium), st.1, gr.2; and she has been operated - hysterectomy with uterine appendages, resection of the greater omentum.

Intraoperative: the uterus was not enlarged, the tumor was located in the uterus cavity, in the form of friable sebaceous growths. The right and left ovaries, right fallopian tube were not changed. The left fallopian tube was in the form of sacculated tumor with a next size: $4.0 \times 4.0 \times 3.5 \mathrm{~cm}$. On the cut the lesion tube was like a cavity, it was filled by gray-pink masses in the form of cauliflower (Fig. 2).

On the left, fallopian tube in the sacculated tumor mass form, on the cut in the form of a cauliflower; the left ovary is normal (1). In the uterine cavity the tumor is in the form of loose sebaceous growths (2).

Histological tissue characteristics were studied with using of serial stepped sections, stained with hematoxylin and eosin. The result of histological studies: 1. Endometrium tumor - highly differentiated endometrial adenocarcinoma with superficial invasion into myometrium (M8140/3 $G_{1}$ - the absence areas of a solid structure, with prevalence of low nuclei atypia of the epithelial cells) (Fig. 3-1). 2. The left fallopian tube tumor - serous papillary adenocarcinoma of the fallopian tube with tumor invasion into the muscle layer (M8441/3 $\mathrm{G}_{2}$ - tumor consisting of short papillary structures with dense fibrous stroma, atypia, polymorphism and hyperchromatosis of the nuclei, and high nuclear cytoplasmic ratio) (Fig. 3-2).

To determine the histogenesis of these neoplasias, the stage of their proliferative activity and tumor cells anaplasia, characteristics of prediction and selection of appropriate methods of patient treatment, we conducted the immunohistochemical investigations using the fololowing markers (Table 1).

For immunohistochemical investigations sections were produced with the thickness of 3-4 mcm, which were subjected to the standard process of dewaxing and dehydration in xylol and alcohols in rising concentration. Immunohistochemical reaction was held in two stages: I Incubation with primary monoclonal antibodies in dilution from $1: 100$ to $1: 400$, during the 30 minutes $\left(t=37^{\circ} \mathrm{C}\right)$; 
II - Incubation with secondary antibodies (UltraVision), during the 30 minutes $\left(t=37^{\circ} \mathrm{C}\right)$. As a chromogen diaminobenzidine $\left(\mathrm{t}=37^{\circ} \mathrm{C}, 30\right.$ minutes $)$ was used with Mayer's hematoxylin staining of the negatively stained nuclei.

The immunohistochemical investigations of the endometrium tumor showed the intensive reaction to the estrogen receptors and progesterone. The Ki-67 proliferation marker in the endometrium tumor was weakly positive, only about $10 \%$ of the nuclei were positive. The negative reaction to the anti-p53 antibodies was observed (Fig. 4).

At the same time immunohistochemical investigations of the left fallopian tube tumor showed a negative reaction to the estrogen and progesterone receptors. Very intensive reaction was observed to the anti-Ki-67 antibodies, where more than a $90 \%$ of tumor nuclei were positive. $\mathrm{Ki}-67$ is a reliable indicator of proliferation in almost all human tumor formations. Also, the intensive reaction was observed with anti-p53 antibodies, where more than $90 \%$ of tumor cells nuclei were positive (Fig. 5).
This aspect of the immunohistochemistry showed that a profound violation of the genetic program with the emergence of mutant p53 gene occurred in this case and a relationship between an increase in the expression of $p 53$ and the growth of morphological atypia and malignancy stage was detected.

The postoperative period was unremarkable. At this time the patient is on a dynamic observation.

\section{Discussion}

PFTC is the most rare malignant tumor of the female genital organs $[1,9]$. To date, in the United States about 2,000 cases of the PFTC were reported [10]. FTC is the most often found after the fourth decades of the life, with an average age of 62 years (17-88 years) [11,12]. The total five-year survival ranges from $14 \%$ to $57 \%$ $[4,9]$. The rare occurrence of the FTC allows asserting that the experience of even a small number of observations
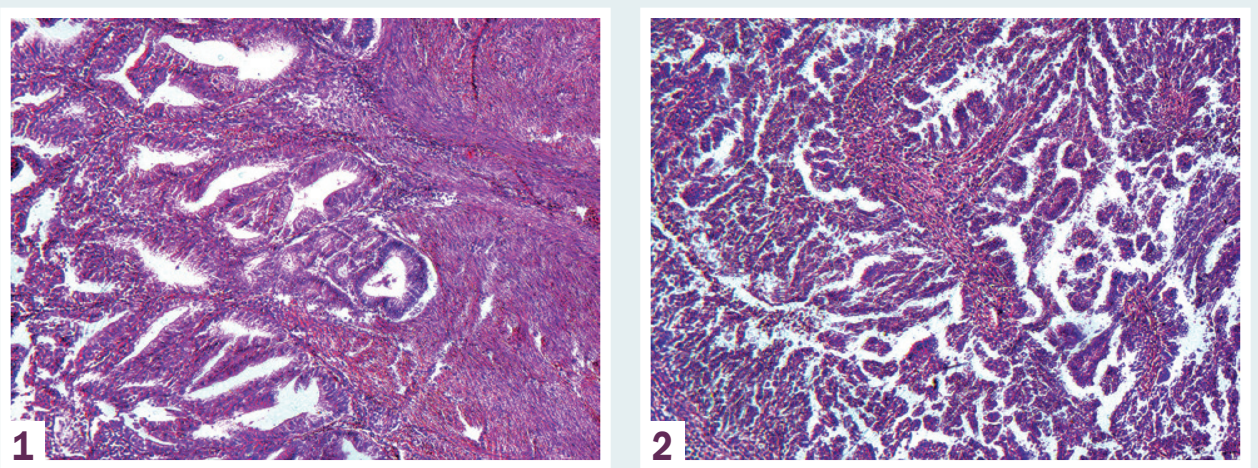

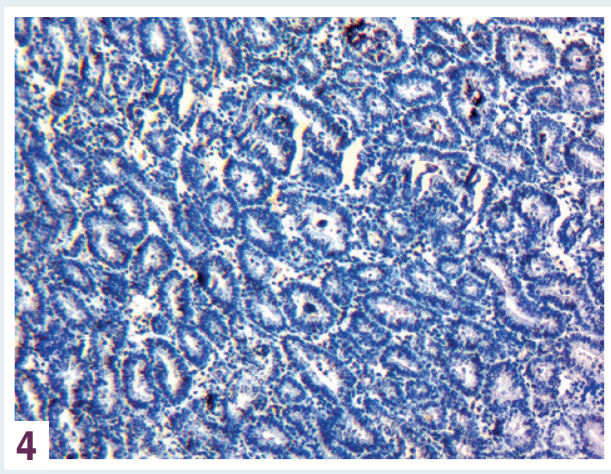

Fig. 3. The tumor of endometrium (1) and left fallopian tube (2). Staining with hematoxylin-eosin.

Zoom $\times 100$.
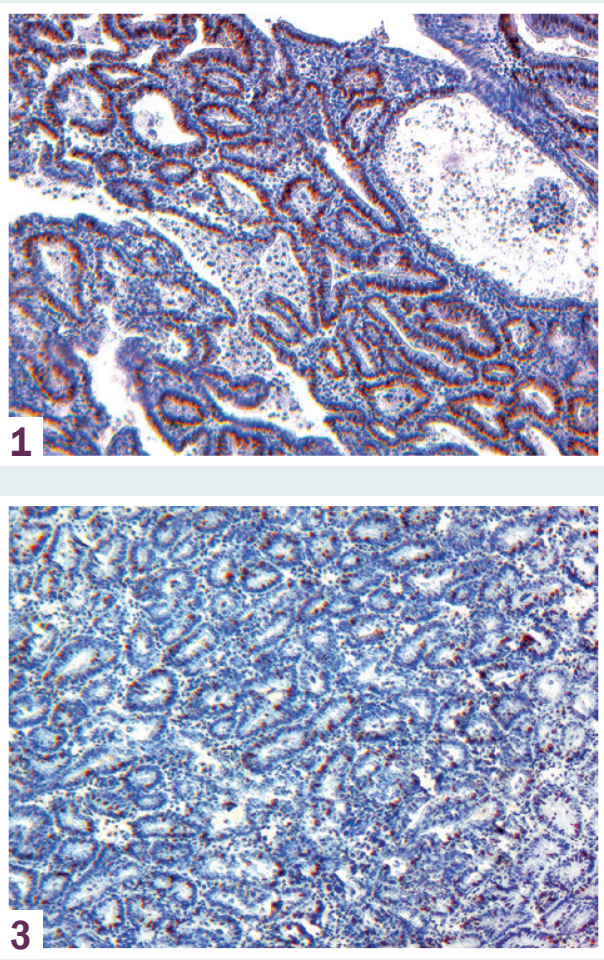

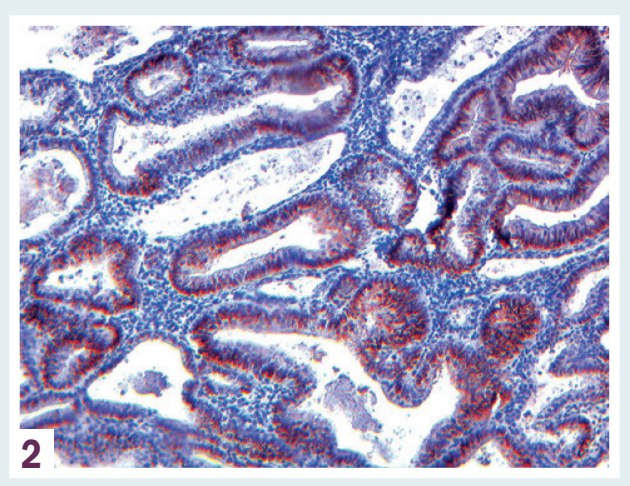

Fig. 4. The tumor of endometrium.

1: intensely positive tumor cells for estrogen receptors;

2: intensely positive tumor cells for progesterone receptors:

3: weak positive reaction to the $\mathrm{Ki}-67$; 4: negative reaction to $p 53$. The immunohistochemical reactions.

Zoom $\times 100$. 

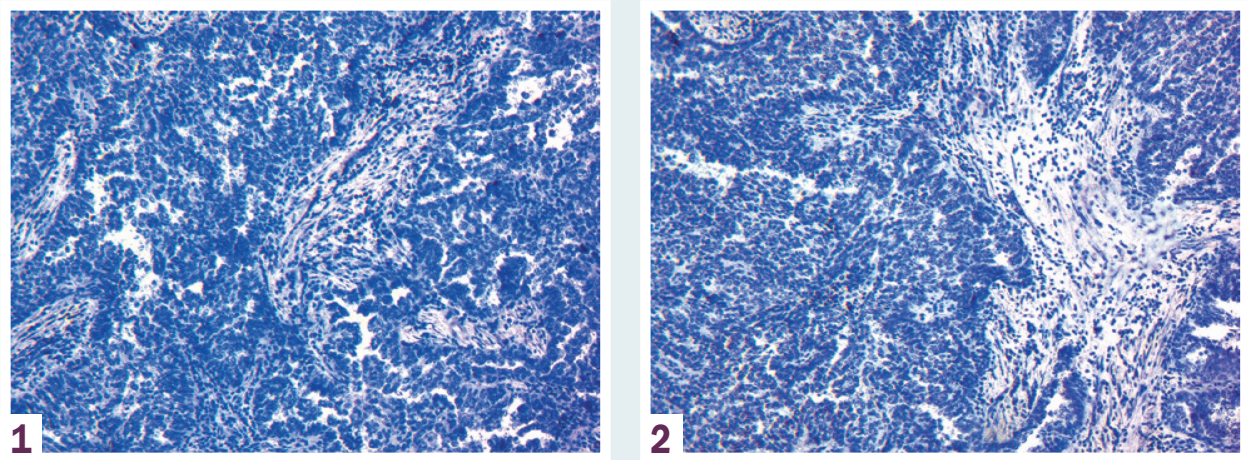

Fig. 5. The left fallopian tube

1: negative tumor cells for estrogen receptors;

2: negative tumor cells for progesterone receptors;

3: intensely positive reaction to

the Ki-67;

4: intensely positive reaction to

the p53. The immunohistochemical

reactions

Zoom $\times 100$
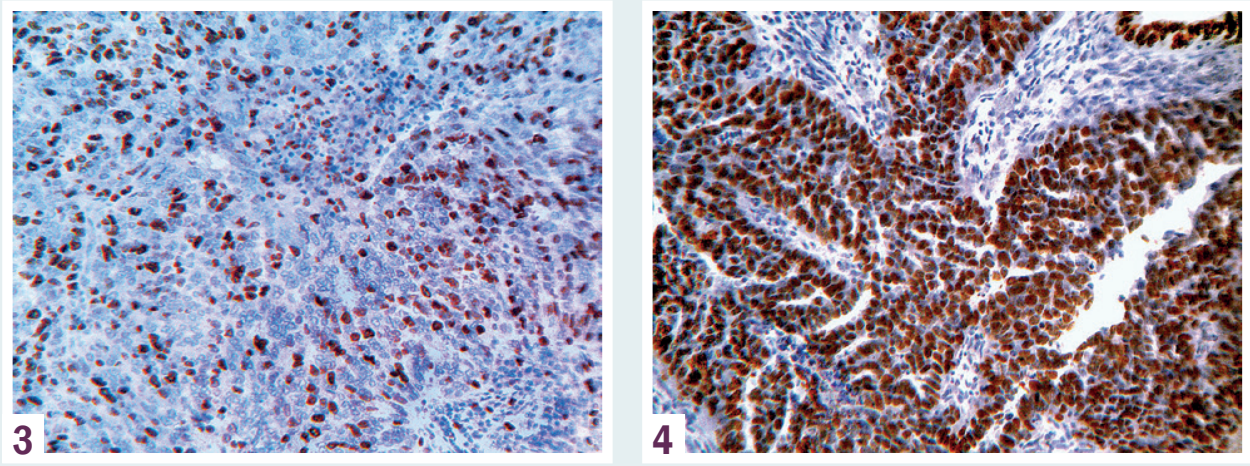

has an undoubted scientific and practical interest. Many authors believe that the actual incidence of the PFTC is much higher, because the most cases of serous carcinoma are erroneously diagnosed as ovarian cancer. You cannot find enough information in the literature about the simultaneous presence of endometrium and fallopian tube tumors either. These neoplasias at an early stage are asymptomatic, in connection with that the diagnosis is rarely set on the pre-operative stage. The most common symptoms of PFTC are abdominal pain, vaginal bleeding, watery discharge from the genital tract, general condition impaired and palpation of tumor formation in the pelvis [11]. In this case the symptoms were meager, and maybe associated with the presence of endometrial tumor. The differential diagnosis of these two locations is quite complicated. Determining the level of tumor marker CA-125 in the blood serum is very important in FTC diagnostics. However, in this case, the research was not conducted. For better FTC diagnostics it is reasonable to conduct a comprehensive survey which includes the ultrasound examination, computed tomography, a diagnostic laparoscopy with biopsy and tumor marker CA-125 determination.

The results of histological and immunohistochemical research showed that in this case there were two absolutely different tumors, which have different sensitivity to the treatment and prognosis. Moreover, adventitiously detected fallopian tube tumor had more unfavorable indicators (a lower degree of differentiation, the absence of steroid receptors, high level of the Ki-67 and p53 receptors expression), as compared with uterus body tumor.

All aforesaid demonstrates the necessary of individual approach to each case of the FTC and requires a separate choice of the treatment tactics, with considering independent prognostic disease factors.

\section{Conclusion}

Primary fallopian tubes carcinoma is a rare disease with an insufficiently studied etiology. The clinical manifestations are not always present in full. Diagnosis in pre-operative period is very hard to establish. Only the qualitative morphological investigation allows establishing the primary lesion of the fallopian tube. Introducing immunohistochemical investigations in practice serves as additional methods for correct diseases diagnostic, which allow more fully characterizing the prognosis and suggesting appropriate treatment of the patients.

Conflicts of Interest: authors have no conflict of interest to declare. Конфлікт інтересів: віАсутній.

Information about authors:

Romaniuk A. M., MD, PhD, DSc, Professor, Head of the Pathology Department, Sumy State University, Ukraine.

Gyryavenko N. I., MD, Assistant of the Pathology Department, Sumy State University, Ukraine.

Lyndin M. S., MD, PhD, Assistant of the Pathology Department, Sumy State University, Ukraine.

Sikora V. V., MD, Postgraduate Student of the Pathology Department, Sumy State University, Ukraine.

Piddubnyi A. M., MD, Postgraduate Student of the Pathology Department, Sumy State University, Ukraine.

\section{Відомості про авторів:}

Романюк А. М., А-р мед. наук, професор, зав. каф. патологічної анатомії, Сумський Аержавний університет, Україна.

Гирявенко Н. І., асистент каф. патологічної анатомії, Сумський Аержавний університет, Україна.

Миндін М. С., канд. меА. наук, асистент каф. патологічної анатомії, Сумський державний університет, Україна.

Сікора В. В., аспірант каф. патологічної анатомії, Сумський Аержавний університет, Україна. 
ПіАдубний А. М., аспірант каф. патологічної анатомії, Сумський Аержавний університет, Україна.

\section{Сведения об авторах:}

Романюк А. Н. А-р меА. наук, профессор, зав. каф. патологической анатомии, Сумский государственный университет, Украина.

Гирявенко Н. И., ассистент каф. патологической анатомии, Сумский государственный университет, Украина.

Аындин Н. С., канА. меА. наук, ассистент каф. патологической анатомии, Сумский государственный университет, Украина. Сикора В. В., аспирант каф. патологической анатомии, Сумский государственный университет, Украина.

Подаубный А. М., аспирант каф. патологической анатомии,

Сумский государственный университет, Украина.

Надійшла Ао реАакції / Received: 28.11.2017

Після Аоопрацювання / Revised: 27.12.2017

Прийнято Ао Аруку / Accepted: 15.02.2018

\section{References}

[1] Tavassoli, F. A., \& Devilee, P (2003). World Health Organization Classification of Tumours. Pathology and Genetics of Tumours of the Breast and Female Genital Organs IARC Press. Lyon.

[2] Rosenblatt, K. A., Weiss, N. S., \& Schwartz, S. M. (1989). Incidence of malignant fallopian tube tumors. Gynecol Oncol, 35, 236-9. doi: https:// doi.org/10.1016/0090-8258(89)90051-6.

[3] Benoit, M. F., \& Hannigan, E. V. (2006). A 10-year review of primary fallopian tube cancer at a community hospital: a high association of synchronous and metachronous cancers. Int. J. Gynecol. Cancer, 16(1), 29-35. doi: 10.1111/j.1525-1438.2006.00292.x.

[4] Yuen, J. H., Wong, G. C., \& Lam, C. H. (2002). Preoperative sonographic diagnosis of primary fallopian tube carcinoma. $J$ Ultrasound Med, 21(10), 1171-1173. doi: 10.7863/jum.2002.21.10.1171.

[5] Pectasides, D., Pectasides, E., \& Economopoulos, T. (2006). Fallopian tube carcinoma: a review. Oncologist, 11, 902-912. doi: 10.1634/ theoncologist.11-8-902.

[6] Benedet, J. L., Bender, H., Jones, H., Nagan, H. Y., \& Pecorelli, S. (2000). FIGO staging classifications and clinical practice guidelines in the management of gynaecological cancers. FIGO Committee on Gynecologic Oncology. Int J Gynaecol Obstet, 70, 209-62. doi: 10.1016/ S0020-7292(00)90001-8.

[7] Colgan, T. J. (2003). Challenges in the early diagnosis and staging of Fallopian tube carcinomas associated with BRCA mutations. Int $\mathrm{J}$ Gynecol Pathol, 22, 109-20.

[8] Tong, S. Y., Lee, Y. S., Park, J. S., Bae, S. N., Lee, J. M., \& Namkoong, S. E. (2008). Clinical analysis of synchronous primary neoplasms of the female reproductive tract. Eur J Obstet Gynecol Reprod Biol, 136, 78-82. doi: 10.1016/j.ejogrb.2006.09.010.

[9] Nordin, A. J. (1994). Primary carcinoma of fallopian tube: a 20-year literature review. Obstet Gynecol Surv, 49, 349-61.

[10] Oliveira, C., Duarte, H., Bartosch, C., \& Fernandes, D. (2013). Small fallopian tube carcinoma with extensive upper abdominal dissemination: a case report. J Med Case Rep, 7(1), 252. doi: 10.1186/1752-1947-7-252.

[11] Deffieux, X., Morice, P., Thoury, A., Camatte, S., Duvillard, P., \& Castaigne, D. (2005). Extension lymphatique pelvienne et lombo-aortique dans le cancer de la trompe: topographie et implications chirurgicales. Gynecol Obstet Fertil, 33(1-2), 23-8. doi: 10.1016/j. gyobfe.2004.11.008.

[12] Pectasides, D., Pectasides, E., Papaxoinis, G., Andreadis, C., Papatsibas, G., Fountzilas, G. et al. (2009). Primary fallopian tube carcinoma: Results of a retrospective analysis of 64 atients. Gynecol Oncol., 115(1), 97-101. doi: 10.1016/j.ygyno.2009.06.025. 